\title{
ADDITIVE EFFECT OF PHOSPHORUS COMPOUNDS UPON THE PREPARATION OF COPOLY(ESTER-AMIDE)S BY DIRECT POLYCONDENSATION USING DIPHENYL CHLOROPHOSPHATE
}

\author{
By Fukuji Higashi and Hideo Arikawa
}

(Department of Polymer Engineering, Tokyo University of Agriculture and Technology, Koganei, Tokyo 184 Japan)

\begin{abstract}
The direct polycondensations of aromatic dicarboxylic acids, bisphenols, and diamines using diphenyl chlorophosphate in the presence of phosphorus compounds were studied. Addition of the phosphorus compounds prevented effectively the gelation of the reaction mixture and produced soluble copolymers even if a high molar percentage of diamines was added. Based on the NMR study, it is considered that the reactivity of the phenolic groups of bisphenols increased due to the hydrogen-bond association with the phosphorus compounds resulting in change of the relative reactivity to diamines. This may lead to favorable monomer sequences in copolymers for the improvement of solubility and the prevention of gelation in the reaction mixture. The changes of monomer sequences caused by the phosphorus compounds were investigated also in terms of optical anisotropy of the copolymers prepared from isophthalic and tere-phthalic acids, methylhydroquinone, and diamines.
\end{abstract}

\section{INTRODUCTION}

We have shown a successful preparation of high molecular weight copoly(ester-amide)s by the direct poly. condensation of aromatic dicarboxylic acids, bisphenols. and diamines using diphenyl chlorophosphate (DPCP) in pyridine. $^{1.2)}$ The reaction proceeded homogeneously without gelation by sequential addition of bisphenols and then diamines, giving soluble copolymers of various com. binations of bisphenols and relatively high molar \% diamines. These facts were assumed to be due to favorable sequences of monomers in the copolymers, which were roughly estimated from optically anisotropic char. acteristics of the copolymers prepared from isophthalic (IPA) and terephthalic (TPA) acids, methylhydroquinone (MeHQ), and diamines. ${ }^{3)}$

Without the troublesome procedure of stepwise addi. tion of the monomers as mentioned above, simultaneous addition also might change the sequences, when the relative reactivity of bisphenols to diamines could be mod. ified by complexation with some reagents. Gramstad ${ }^{4)}$ showed strong hydrogen-bond association of phenols especially with phosphorus compounds. Among phos. phorus compounds, phosphine oxides had high associat. ing ability.

To examine the effect of complexation of monomers with phosphorus compounds upon the monomer sequences of the resulting copolymers and therefore upon their solubility, we carried out the copolycondensation of IPA, TPA, bisphenols, and diamines using DPCP and triphenylphosphine oxide (TPPO) which is commercially available and easy to handle. The sequneces of the copolymers obtained were studied in terms of their solu. bility and optical anisotropic characteristics.

\section{RESULTS AND DISCUSSION}

Copolycondensations of IPA, $50 \mathrm{~mol} \%$ TPA, bisphe nols, and diamines in pyridine were carried out by the slow addition of a pyridine solution of a mixture of bis phenols, diamines, and TPPO, as described in the pre vious paper. ${ }^{3)}$ Optical anisotropies of the copolymers obtained were determined by the temperature above which complete birefringence was observed under zero shear by use of a polarizing microscope equipped with a hot-stage. 


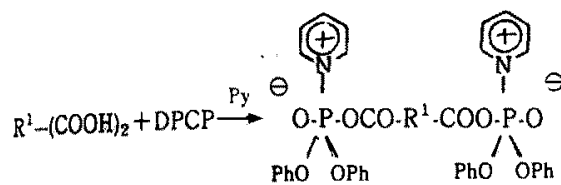

$\mathrm{R}^{2}-(\mathrm{OH})_{2} / \mathrm{R}^{3}-\left(\mathrm{NH}_{2}\right)_{2} / \mathrm{TPPO} / \mathrm{Py}$

$\rightarrow+O C-R^{1}-C O O-R^{2}-O_{m}+N H-R^{3}-N H O C-R^{1}-C_{*}$

Copolycondensation of IPA, TPA, 2, 2-bis (4-hydroxyphenyl)propane (BPA), and $50 \mathrm{~mol} \%$ of $4,4^{\prime}$-oxydianiline (ODA) was carried out in the presence of TPPO (Table 1). As previously reported, ${ }^{2)}$ simultaneous addition of $B P A$ and ODA resulted in the gelation to give an insolu. ble copolymer whereas the sequential addition of BPA and then ODA gave a soluble copolymer without gelation. However, when TPPO was present, the reaction, even upon the spontaneous addition of BPA and ODA, proceeded homogeneously and gave a soluble copolymer with high inherent viscosity.

Table 1 Additive Effect of TPPO on the copolycondens. ation of IPA, TPA, BPA, and 50 mot \% ODA in Pyridine ${ }^{\text {a) }}$

\begin{tabular}{ccc}
\hline TPPO(mmol) & State & $\eta_{\mathrm{inh}}{ }^{c)}$ \\
\hline 0 & Gelation & Insoluble \\
$0^{\mathrm{b})}$ & Solution & 1.40 \\
5 & Solution & 1.33 \\
10 & Solution & 1.14 \\
\hline
\end{tabular}

a) TPA. IPA, BPA, ODA $=2.5 \mathrm{mmol} ; \mathrm{DPCP}=12 \mathrm{mmol}$; $P y=30 \mathrm{ml}$; addition of BPA $/ O D A / T P P O=20 \mathrm{~min}$.

b) The reaction was carried out by sequential addition of BPA for $5 \mathrm{~min}$ and then ODA for $5 \mathrm{~min}$.

c) Measured in 60:40 phenol/sym-tetrachloroethane (PTCE) at $30^{\circ} \mathrm{C}$.
The copolycondensations with $50-90 \mathrm{~mol} \%$ ODA were carried out in the presence of an equivalent amount of TPPO with respect to hydroxy groups of BPA (Table 2). In the copolycondensations with more than $60 \mathrm{~mol} \%$ ODA in the absence of TPPO, gelation occurred by both simultaneous and sequential addition of BPA, and ODA. and the resulting copolymer with $80 \mathrm{~mol} \%$ ODA, for ex. ample, was insoluble in 60:40 phenol/ sym-tetrachloroethane(PTCE) : only the copolymer prepared by sequen tial addition was soluble in p-chlorophenol. However. the reaction using more than $80 \mathrm{~mol} \%$ ODA in the presence of TPPO gave copolymer which was soluble in PTCE or in DMAC/ $\mathrm{LiCl}(5 \%)$ solvent.

As described above, the gelation of the reaction mixture and the solubility of the copolymers prepared by the simultaneous addition of BPA and ODA were significant. ly improved by the presence of TPPO as well as by the sequential addition of BPA and ODA. These facts led us to consider that TPPO might promote the reactivity of $B P A$ via hydrogen-bond association even in the presence of ODA so that alcoholysis with BPA might ocurr easily. as observed by the initial reaction of BPA in the sequen. tial addition.

The association of the phosphorus compounds with phenol was studied by means of IR spectroscopy. The association constant, $K_{\text {ass }}$ for the association of phenol with TPPO and with triethylphosphine oxide determined at $20^{\circ} \mathrm{C}$ in carbon tetrachloride were 1055.4 and 2522.0 , respectively, showing that the latter has higher ability of the association than the former. Tributylphos. phine oxide may have high $\mathrm{K}_{\mathrm{ass}}$ and association ability as those of triethylphosphine oxide, though it has not been reported.

Table 2 Additive Effect of TPPO on the Copolycondensation of IPA. TPA, BPA, and Several mol \% ODA in Pyridine ${ }^{\text {a) }}$

\begin{tabular}{|c|c|c|c|c|c|c|}
\hline \multirow{3}{*}{$\begin{array}{l}\text { ODA } \\
(\mathrm{mol} \%)\end{array}$} & \multirow{2}{*}{\multicolumn{2}{|c|}{$\frac{\text { This work }}{\text { simultaneous addition }}$}} & \multicolumn{4}{|c|}{ Previous work ${ }^{3)}$} \\
\hline & & & \multicolumn{2}{|c|}{ simultaneous addition } & \multicolumn{2}{|c|}{ sequential addition } \\
\hline & State & $\eta_{\mathrm{inh}}{ }^{b)}$ & State & $\eta_{\text {inh }^{b)}}$ & State & $\eta_{\text {inh }}{ }^{b)}$ \\
\hline 50 & Solution & 1.15 & Solution & 1.38 & Solution & 1.40 \\
\hline 80 & Solution & 1.28 & Gelation & Insoluble & gelation & $1.26^{d \xi}$ \\
\hline 90 & Solution & $1.75^{\mathrm{c})}$ & - & - & - & - \\
\hline
\end{tabular}

a) IPA, TPA = $2.5 \mathrm{mmol}: \mathrm{BPA}+\mathrm{ODA}=5 \mathrm{mmol} ; \mathrm{DPCP}=12 \mathrm{mmol} ; \mathrm{TPPO}=10 \mathrm{mmol} ; \mathrm{Py}=30 \mathrm{ml}$; simultaneous addition of BPA/ODA/ TPPO $=10 \mathrm{~min}$; simultaneous addition of BPA/ODA for $10 \mathrm{~min}$, and sequential addition of BPA for 5 min and then ODA for 5 min in previous work ${ }^{3)}$

b) Measured in $60: 40$ phenol $/$ sym-tetrachloroethane at $30^{\circ} \mathrm{C}$.

c) Measured in $\mathrm{DMAc} / \mathrm{LiCl}(5 \%)$ at $30^{\circ} \mathrm{C}$.

d) Measured in p-chlorophenol at $50^{\circ} \mathrm{C}$. 
In this experiment we examined the association of several phosphorus compounds with BPA and ODA in pyridine by means of NMR spectroscopy. Similar phe. nomena were also observed in NMR spectra as shown in Table 3. BPA in pyridine showed a peak at $11.23 \mathrm{ppm}$

Table 3 Proton Shifts of Phosphorus Compound.BPA Complexes in Pyridine ${ }^{\text {a) }}$

\begin{tabular}{lc}
\hline Phosphorus compound & $\begin{array}{c}\delta \text {-value } \\
\text { (ppm) }\end{array}$ \\
\hline None & 11.23 \\
Triphenyl phosphate & 11.29 \\
Trimethyl phosphate & 10.99 \\
Triphenylphosphine oxide & 10.99 \\
Tributylphosphine oxide & 10.66 \\
Hexamethylphosphoramide & 10.66 \\
\hline
\end{tabular}

a) Measured in pyridine solution that contained $10 \mathrm{wt} \%$ BPA (5 mmol), phosphorus compounds (10 $\mathrm{mmol})$, and TMS as internal reference at room temperature.

due to phenolic protons. When the phosphorus compounds with higher ability to form intermolecular hyd. rogen bonds with phenol were present, the peak shifted to much higher magnetic fields. On the other hand, no substantial change in the $\mathrm{NH}_{2}$ peak at $5.14 \mathrm{ppm}$ was observed by addition of the phosphorus compounds.

To investigate complexation effect of TPPO on the monomer sequences in copolymers in terms of the charac

Table 4 Copolycondensation of IPA, TPA, MeHQ, and 20 mol \% ODA in the Presence of TPPO in Py. ridine $^{\text {a) }}$

\begin{tabular}{cclc}
\hline $\begin{array}{c}\text { TPPO } \\
(\mathrm{mmol})\end{array}$ & $\begin{array}{c}\text { Birefringence } \\
\left({ }^{\circ} \mathrm{C}\right)\end{array}$ & State & $\eta_{\mathrm{inh}}{ }^{\mathrm{b})}$ \\
\hline None &, 260 & Precipitation & 1.07 \\
5 & $>250$ & Less precipitation & 1.23 \\
10 &, 240 & Less precipitation & 1.17 \\
\hline
\end{tabular}

a) IPA, TPA $=2.5 \mathrm{mmol} ; \mathrm{MeHQ}=4 \mathrm{mmol} ; \mathrm{ODA}=1$ mmol; DPCP $=12 \mathrm{mmol} ; \mathrm{Py}=30 \mathrm{ml}$; time for addi. tion of MeHQ/ODA/TPPO $=10 \mathrm{~min}$.

b) Measured in p-chlorophenol at $50^{\circ} \mathrm{C}$.

teristics other than gelation and copolymer solubility, the copolycondensation of IPA, TPA, MeHQ, and $20 \mathrm{~mol} \%$ ODA was carried out in the presence of TPPO. The copolymer was found to show optical anisotropy at a temperature above $260^{\circ} \mathrm{C}$, when prepared by the reaction with DPCP. ${ }^{31}$ The reaction in the presence of TPPO was accompanied by less precipitation than the case of
Table 5 Copolycondensation of IPA, TPA, MeHQ, and 20 mol \% ODA in the Presence of Several Phos. phorus Compounds ${ }^{\text {a) }}$

\begin{tabular}{lcc}
\hline Phosphorus compound & $\begin{array}{c}\text { Birefringence } \\
\left({ }^{(} \mathrm{C}\right)\end{array}$ & $\eta_{\mathrm{inh}}^{\mathrm{b})}$ \\
\hline None & 1260 & 1.07 \\
Triphenylphosphine oxide & 1240 & 1.17 \\
Tri- $n$-butylphosphine oxide & 1220 & 0.98 \\
Hexamethylphosphoramide & $>225$ & 0.63 \\
\hline
\end{tabular}

a) $\mathrm{IPA}, \mathrm{TPA}=2.5 \mathrm{mmol} ; \mathrm{MeHQ}=4 \mathrm{mmol} ; \mathrm{ODA}=$ $1 \mathrm{mmol} ; \mathrm{DPCP}=12 \mathrm{mmol}$; phosphorus compound = $10 \mathrm{mmol}: \mathrm{Py}=30 \mathrm{ml}$; time for addition of $\mathrm{MeHQ}$ / $\mathrm{ODA} /$ phosphor us compound $=10 \mathrm{~min}$.

b) Measured in p-chlorphenol at $50^{\circ} \mathrm{C}$.

without TPPO, and gave a copolymer exhibiting optical anisotropy at lower temperatures, suggesting the formation of the copolymer with different solubility and thermal properties (Table 4). Similarly. the copoly. condensations were carried out in the presence of one equivalent of several phosphorus compounds with respect to monomers (Table 5). The resulting mixtures were viscous solutions with some precipitates so that they were all diluted with about three times of pyridine to give copolymers in quantitative yield. Although one of the copolymers prepared in hexamethylphosphoramide (HMPA) showed a somewhat low inherent viscosity, other copolymers may have high enough molecular weight to discuss their optically anisotropic characteristics regardless of the effect of the molecular weight on the anisotropy. The resulting copolymers exhibited anisotropic melts at temperatures lower than $260{ }^{\circ} \mathrm{C}$ which was corresponding to the anisotropic melting temperature for the copolymer prepared in the absence of the phos. phorus compounds.

Judging from the NMR data for the hydrogen-bonding association of BPA with phosphorus compounds listed in Table 3 , the phosphorus compounds with higher ability of association gave the copolymer showing the anisotropy at lower temperatures. This may be due to significant promotion of the reactivity of MeHQ. leading to the ran dom sequences of ODA in the copolymer even by simul. taneous addition of MeHQ and ODA.

Copolycondensations of IPA, TPA, MeHQ, and $20 \mathrm{mo}$ lar percentage of several diamines were conducted in the presence of TPPO to examine the effect of the basicity (nucleophilicity) of diamines on the optical anisotropy of 
Table 6 Copolycondensations of IPA, TPA, MeHQ, and $20 \mathrm{~mol} \%$ Various Diamines in the Presence of $\mathrm{TPPO}^{\mathrm{a})}$

\begin{tabular}{lll}
\hline Diamine $^{(b)}$ & $\begin{array}{c}\text { Birefringence } \\
(\mathrm{C})\end{array}$ & $\eta_{\mathrm{inh}^{\mathrm{c}}}{ }^{\mathrm{ce})}$ \\
\hline ODA &, $240(>230)$ & $1.17(1.12)$ \\
MDA & $>260\left(>240^{\mathrm{d})}\right)$ & $0.92(1.0)$ \\
TDA &, $270(2260)$ & $0.86(0.89)$ \\
PPD &, $300(3300)$ & $0.89(1.24)$ \\
\hline
\end{tabular}

g) $\mathrm{PAA}, \mathrm{TPA}=2.5 \mathrm{mmol} ; \mathrm{MeHQ}=4 \mathrm{mmol} ;$ diamine $=1$ mmol; $\mathrm{DPCP}=12 \mathrm{mmol} ; \mathrm{TPPO}=10 \mathrm{mmol} ; \mathrm{Py}=30$ ml; time for addition of MeHQ/diamine/TPPO $=10$ min.

b) $\mathrm{ODA}=4,4^{\circ}$-oxydianiline; $\mathrm{MDA}=4,4^{\prime}$-methy lenedianiline: $T D A=4,4^{\prime}$ thioxydianiline; $\mathrm{PPD}=p$-phenylenediamine.

c) Values in parentheses were obtained by the reaction of sequential addition of MeHQ and diamines in the absence of TPPO. ${ }^{37}$

d) Partially birefringent without shear, but completely under shear.

e) Measured in $p$-chlorophenol at $50^{\circ} \mathrm{C}$.

the resulting copolymers, and results were compared with those previously obtained by sequential addition of MeHQ and diamines in the absence of TPPO (Table 6). The results of this experiment were nearly comparable to those in the previous work, suggesting that the reaction of MeHQ was facilitated by TPPO as favorable as achieved by sequential initial addition of MeHQ. It is interesting to note that the copolymer with $4,4^{\prime}$. methylenedianiline (MDA) showed complete anisotropy above $260^{\circ} \mathrm{C}$, despite the fact that only partial anisotropy was observed for the copolymer prepared by sequential addition. These facts indicate that TPPO and other phoshorus compounds promote the formation of re. latively highly homogeneous copolymers instead of being contaminated by some amounts of block copolymer.

\section{EXPERIMENTAL}

Copolycondensations of IPA, TPA, Bisphenols, and Diamines in the Presence of Phosphorus Compounds

A mixture of DPCP (12 mmol). IPA $(2.5 \mathrm{mmol})$, and TPA (2.5 mmol) in pyridine $(20 \mathrm{ml})$ prepared as previously described ${ }^{23}$, was maintained at room temperature for $20 \mathrm{~min}$ and then at $120^{\circ} \mathrm{C}$ (bath temperature) for 10 min. To the hot solution, a pyridine solution of bisphenols $(0.5 .4 \mathrm{mmol})$, diamines $(4.5 .1 \mathrm{mmol})$, and phosphorus compounds $(0.10 \mathrm{mmol})$ was added dropwise over 10 $20 \mathrm{~min}$, and the whole mixture was further heated at $120^{\circ} \mathrm{C}$ for $3 \mathrm{~h}$. The resulting mixtures were diluted with pyridine and poured into methanol to isolate the copolymers, and the precipitated polymers were filtered and washed with boiling methanol. The dried and pulverized samples were subjected to anisotropic measurement. The anisotropy was determined by the temperature above which complete birefringence was observed under zero shear by use of a polarizing microscope equipped with a heating stage.

\section{References}

1) F. Higashi, M. Ozawa, A. Hoshino, and A. Mochizuki, J. Polym. Sci. Polym. Chem. Ed., 23, 1699 (1985).

2) F. Higashi, M. Ozawa, and A. Mochizuki, J. Polym. Sci. Polym. Chem. Ed., 24, 637 (1986).

3 ) F. Higashi, H. Arikawa, and A. Mochizuki, J. Polym. Sci. Polym. Chem. Ed., 26, 3071 (1988).

4) T. Gramstad, Spectrochim. Acta, 19, 497 (1963).

\section{クロルりん酸ジフェニルエステルを用いた直接重縮合による コポリエステルアミド合成におけるりん化合物の添加効果}

\section{東京農工大学工学部 東 福 次, 蟻 川 英 男}

クん化合物の存在下にクロルりん酸ジフェニルエスデ ルを用いた芳香族ジカルボン酸，ビフェノール，ジアミ ンの直接重䊒合を検討した。りん化合物の添加でゲル化 加防止でき，ジアミン含量の高い可溶性コボリマーも合 成でき。NMRより，フェノール性水酸基の反応性が りん化合物との水素結合によって向上し，ジアミンとの
相対反応性が変化し，これらの結果，モノマー配列が変 化して溶解性向上やゲル化防止に効果があると結論した。 このモノマー配列の変化をイソフタル酮, テレフタル酸, メチルヒドロキノン，およびジアミンからのコポリマー の光学異方性からも検討した。 